\title{
Nonclassical T Cells and Their Antigens in Tuberculosis
}

\author{
Gennaro De Libero ${ }^{1,2}$, Amit Singhal ${ }^{1}$, Marco Lepore ${ }^{2}$, and Lucia Mori ${ }^{1,2}$ \\ ${ }^{1}$ SIgN (Singapore Immunology Network), A*STAR (Agency for Science, Technology and Research), \\ 138648 Singapore \\ ${ }^{2}$ Experimental Immunology, Department of Biomedicine, University Hospital Basel, $\mathrm{CH}-4031$ \\ Basel, Switzerland \\ Correspondence: gennaro_delibero@immunol.a-star.edu.sg
}

T cells that recognize nonpeptidic antigens, and thereby are identified as nonclassical, represent important yet poorly characterized effectors of the immune response. They are present in large numbers in circulating blood and tissues and are as abundant as T cells recognizing peptide antigens. Nonclassical T cells exert multiple functions including immunoregulation, tumor control, and protection against infections. They recognize complexes of nonpeptidic antigens such as lipid and glycolipid molecules, vitamin $B_{2}$ precursors, and phosphorylated metabolites of the mevalonate pathway. Each of these antigens is presented by antigen-presenting molecules other than major histocompatibility complex (MHC), including CD1, MHC class I-related molecule 1 (MR1), and butyrophilin 3A1 (BTN3A1) molecules. Here, we discuss how nonclassical $\mathrm{T}$ cells participate in the recognition of mycobacterial antigens and in the mycobacterial-specific immune response.

$\mathrm{T}_{\mathrm{ic}}^{\mathrm{h}}$ he recognition by T lymphocytes of antigenic complexes formed by antigens and antigen-presenting molecules is a hallmark of the adaptive immune system. A wide range of exogenous and endogenous antigenic molecules reflecting a variety of chemical structures have been identified and are represented by proteins, lipids, phosphorylated metabolites, or vitamin $\mathrm{B}_{2}$ pathway metabolites. The role of classical T cells, which recognize peptidic antigens associated with $\mathrm{MHC}$-encoded molecules, during Mycobacterium tuberculosis (MTB) infection is well documented and studied for a long time (Cooper 2009). On the contrary, nonclassical $\mathrm{T}$ cells recognizing nonpeptidic antigens associ- ated with non-MHC antigen-presenting molecules have been described more recently. They have also been identified as important contributors to host defense against infections, although many aspects of their physiological role still remain to be discovered. Based on the restriction molecule, antigen specificity, and T-cell receptor (TCR) structure, non-MHC-restricted $\mathrm{T}$ cells can be grouped into three categories: lipid- and glycolipid-specific CD1-restricted T cells, mucosal-associated invariant T (MAIT) MR1-restricted cells, and TCR $\gamma \delta$ BTN3A1-restricted $\mathrm{T}$ cells. In this article, we review critical issues of the basic immunobiology of nonMHC-restricted $\mathrm{T}$ cells related to recognition of

Editors: Stefan H.E. Kaufmann, Eric J. Rubin, and Alimuddin Zumla

Additional Perspectives on Tuberculosis available at www.perspectivesinmedicine.org

Copyright (C) 2014 Cold Spring Harbor Laboratory Press; all rights reserved; doi: 10.1101/cshperspect.a018473

Cite this article as Cold Spring Harb Perspect Med 2014;4:a018473 
De Libero et al.

mycobacterial antigens and discuss their roles during MTB infection.

\section{LIPID-SPECIFIC CD1-RESTRICTED T CELLS}

Lipid-specific $\mathrm{T}$ cells recognize lipid antigens as complexes formed with the CD1 antigen-presenting molecules. The human CD1a, CD1b, CD1c, and CD1d proteins bind and present lipid antigens (De Libero and Mori 2006), whereas CD1e behaves as a lipid chaperone, which participates in lipid antigen presentation without interacting with the TCR (Garcia-Alles et al. 2011). The CD1-lipid antigen complexes are mostly formed within antigen-presenting cells (APCs) in compartments where CD1 molecules recycle. Each CD1 molecule has unique modes of intracellular trafficking and thus can intersect with lipids, which also have different trafficking modes within APCs. Several studies have shown how CD1 structure, trafficking, and loading influence lipid antigen presentation, thereby directly contributing to lipid immunogenicity during immune responses (De Libero and Mori 2012). CD1-presented antigens are represented by amphipathic molecules characterized by a hydrophobic moiety, instrumental for binding within the CD1 pockets, and by a polar part, which in most of the cases directly interacts with the TCR.

\section{Structure, Expression, and Intracellular Trafficking of CD1 Molecules}

During mycobacterial infection the activation of lipid-specific T cells occurs upon the generation of stable CD1-lipid antigen complexes, which are formed within APCs. The immunogenicity of mycobacterial lipids is influenced by the type of cell that internalizes the lipid antigen and by the intersection of the lipid antigen with individual CD1 isoforms that recycle in different endosomal compartments.

All CD1 molecules show general structural features similar to MHC class I molecules, including two $\alpha$ helices in the distal $\alpha 1$ and $\alpha 2$ domains and a $\alpha 3$ domain that noncovalently associates with $\beta_{2}$ microglobulin. The antigenbinding groove of CD1 molecules allows inser- tion of the hydrophobic moieties of lipid antigens, whereas the antigenic polar moieties usually remain outside the groove and, along with CD1 key amino acids, interact with the TCRs (Moody et al. 2005; Rossjohn et al. 2012). Among different CD1 molecules, lipid-binding pockets vary in number, shape, and total volume. Together, these structural properties allow selective binding of lipid antigens differing in the number and length of alkyl chains. An important difference between $\mathrm{CD} 1$ and $\mathrm{MHC}$ molecules is a very limited sequence diversity and thus almost absence of functional polymorphism (Han et al. 1999; Porcelli and Modlin 1999). Two examples of CD1 gene polymorphisms were described that influence the response to lipid antigens. The first example concerns CD1d in congenic mice in which CD1d alleles influence development and presentation of endogenous and exogenous ligands to CD1drestricted T cells (Zimmer et al. 2009). The second example applies to CD1e in humans. CD1e gene is the most polymorphic gene of the CD1 family, with six allelic variants reported so far. CD1e is necessary for processing of mycobacterial hexamannosylated phosphatidylinositol mannosides $\left(\right.$ PIM $\left._{6}\right)$ (de La Salle et al. 2005) and controls the generation and persistence of complexes formed by different lipid antigens and all other CD1 molecules (Facciotti et al 2011). The CD1e allele 4 is unable to participate in the presentation of $\mathrm{PIM}_{6}$ to CD1b-restricted specific T cells (Tourne et al. 2008), suggesting that homozygous individuals might display altered immune responses to microbial glycolipid antigens.

A different mechanism controlling the presentation of lipid antigens in the population is represented by regulation of $C D 1$ gene expression. Indeed, a unique SNP in the $5^{\prime}$ untranslated region of the human CD1a gene is associated with altered expression of CD1a and antigen presentation (Seshadri et al. 2013).

The immunological relevance of lipid-specific recognition during mycobacterial infections is also determined by the constitutive or inducible expression of CD1a, b, and c isoforms on unique cell types, indicating distinct roles during immune responses in tissues (Porcelli 
1995; Dougan et al. 2007). CD1d expression is distributed on almost all types of hematopoietic cells (Brossay et al. 1997; Roark et al. 1998) and also on some cells of nonhematopoietic origin, including epithelial cells and adipocytes. Whether CD1d-expressing epithelial cells present mycobacterial antigens at the foci of infection remains to be investigated.

The third important feature of CD1 isoforms is their intracellular trafficking route that determines the encounter with different mycobacterial lipids. CD1 molecules use different trafficking pathways, mainly governed by motifs present in their cytoplasmic tails, which interact with various adaptor protein complexes. Although CD1b, CD1c, and CD1d molecules bind to the adaptor protein 2 and recycle through late endosomes where lipid antigens are loaded (Barral and Brenner 2007), CD1a localizes in membrane rafts and recycles through early endosomes (Barral et al. 2008; Sloma et al. 2008). Mouse CD1d and human CD1b also interact with the adaptor protein 3, responsible for lysosomal trafficking. Lysosomal route is instrumental for binding complex mycobacterial lipids, which require processing and low $\mathrm{pH}$ environment for CD1b loading.

\section{Mycobacterial Lipid Antigens Presented by CD1 Molecules}

Because of their abundance in mycobacterial cell envelope, several mycobacterial lipids are antigenic (Fig. 1; Table 1) (De Libero et al. 2009). Among all CD1 molecules, CD1b binds lipids of different size ranging from C12 to C80 (Beckman et al. 1994; Batuwangala et al. 2004; Guiard et al. 2009; Layre et al. 2009; Garcia-Alles et al. 2011). CD1b-restricted MTB-derived mycolic acid (MA) having $\alpha$-branched $\beta$-hydroxy long chain fatty acid was the first lipid antigen found to stimulate CD1-specific T cells (Beckman et al. 1994). Glucose monomycolate (GMM), an MA with a single glucose molecule, is another CD1b-restricted immunogenic lipid, which is synthesized by pathogenic MTB upon use of glucose derived from its host (Moody et al. 2000a). Recently, a conserved T-cell population expressing TCR $\alpha$ chain with limited junctional variability and with biased selection of TCR $\beta$ chains was detected in the blood of some MTBinfected individuals. This type of conserved TCR has high affinity to mycolyl lipid-CD1b complexes and might be an example of "public" TCR expanding in response to mycobacterial antigen (Van Rhijn et al. 2013).

Glycerol monomycolate (GroMM), a MA with a glycerol, stimulates CD1-restricted lipid-specific $\mathrm{T}$ lymphocytes from TB patients (Layre et al. 2009). Chemical characterization of this antigen showed that it exists as two stereoisomers, one synthetic isomer being more stimulatory than the other. The hydroxyl groups of glycerol and mycolic acid length are critical for triggering T-cell responses. GroMM is presented by MTB-infected dendritic cells (DCs), showing that it is available for presentation during natural infection. Evidence from ex vivo experiments that GroMM stimulates $T$ cells from vaccinated or latently infected donors but not cells from patients with active TB suggests that GroMM-specific T cells are primed during infection and their detection correlates with lack of clinical active disease (Layre et al. 2009). Other CD1b-restricted immunogenic mycobacterial lipids are glycosylphosphatidylinositols. They include phosphatidylinositol mannosides (PIMs) with varying numbers of mannose residues (Sieling et al. 1995; de La Salle et al. 2005), and further extensions of glycosylations like lipomannan (LM) (Ernst et al. 1998) and lipoarabinomannan (LAM) (Sieling et al. 1995). Of particular interest, diacylsulfoglycolipid ( $\mathrm{Ac}_{2} \mathrm{SGL}$ ), found exclusively in the cell envelope of virulent MTB, is a potent antigen that stimulates CD1b- (Gilleron et al. 2004; Layre et al. 2009) and CD1c-restricted immune responses in $\mathrm{TB}$ (Lepore et al. 2014). The length of the linear acyl chain at position 2, the stereochemistry of the methyl-branched fatty acid chain at position 3, and the number of C-methyl-branched acyl groups influence antigenicity. A direct correlation was observed between the T-cell stimulatory capacities of the analogs and the number of methylbranched groups, suggesting that the most abundant sulfoglycolipid form naturally produced by MTB is the most stimulatory one 
De Libero et al.
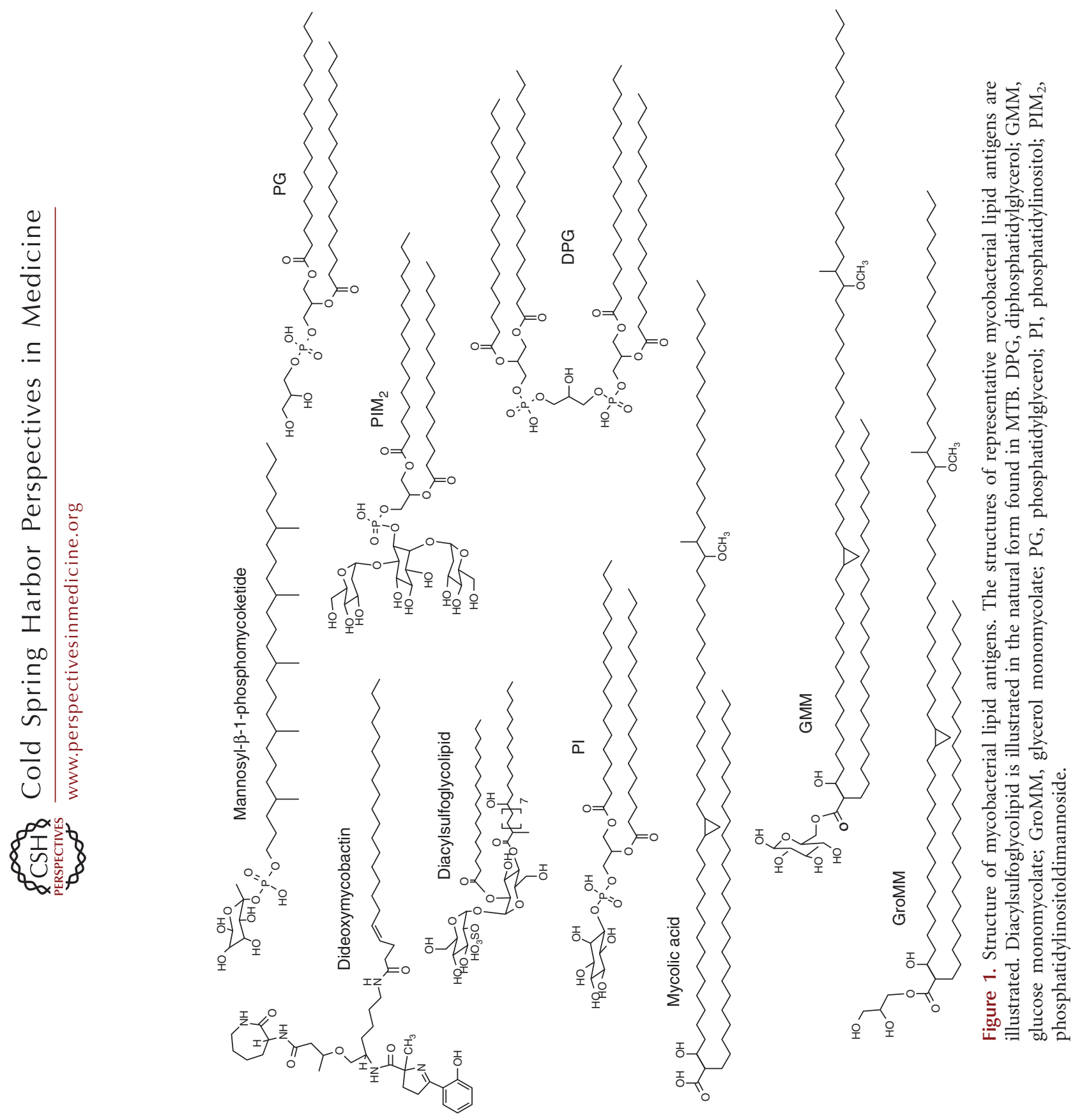
Table 1. Mycobacterial lipid antigens with CD1 restriction

\begin{tabular}{|c|c|c|}
\hline Antigen & CD1 & Reference(s) \\
\hline Dideoxymycobactin & CDla & $\begin{array}{l}\text { Moody et al. 2004; } \\
\text { Kasmar et al. } \\
2013\end{array}$ \\
\hline Diacylsulfoglycolipid & $\mathrm{CD} 1 \mathrm{~b}$ & $\begin{array}{l}\text { Gilleron et al. } \\
2004\end{array}$ \\
\hline Glucose monomycolate & CD1b & Sieling et al. 1995 \\
\hline Glycerol monomycolate & CD1b & Layre et al. 2009 \\
\hline Mycolic acid & $\mathrm{CD} 1 \mathrm{~b}$ & $\begin{array}{l}\text { Beckman et al. } \\
1994\end{array}$ \\
\hline LAM & CD1b & Sieling et al. 1995 \\
\hline LM & CD1b & Sieling et al. 1995 \\
\hline PIMs & CD1b & Sieling et al. 1995 \\
\hline $\begin{array}{l}\text { Mannosyl- } \beta-1- \\
\text { phosphomycoketide }\end{array}$ & CD1c & $\begin{array}{l}\text { Moody et al. } \\
\text { 2000a; } \\
\text { Matsunaga } \\
\text { et al. 2004; Ly } \\
\text { et al. } 2013\end{array}$ \\
\hline PIM & CD1d & Fischer et al. 2004 \\
\hline $\begin{array}{l}\text { Phosphoglycerolipids: } \\
\text { PG, DPG, PI }\end{array}$ & CD1d & Tatituri et al. 2013 \\
\hline
\end{tabular}

LAM, lipoarabinomannan; LM, lipomannan; PIMs, phosphatidylinositol mannosides; PG, phosphatidylglycerol; DPG, diphosphatidylglycerol; PI, phosphatidylinositol.

for T cells (Gau et al. 2013; Geerdink et al. 2013).

A unique mode of binding lipid antigens is that of CD1a. This CD1 isoform shows a quite large and open $\mathrm{F}^{\prime}$ pocket and a deep $\mathrm{A}^{\prime}$ pocket, which bind and present mycobacterial dideoxymycobactin, a single chain lipopeptide precursor in the biosynthesis of mycobactin (Moody et al. 2004; Zajonc et al. 2005; Madigan et al. 2012). Mycobactin being essential in mycobacterial iron acquisition and survival of MTB in vivo (De Voss et al. 2000; Siegrist et al. 2009), the existence of $\mathrm{T}$ lymphocytes targeting cells presenting this type of antigen might represent an important protective mechanism. Another mycobacterial lipid antigen, mannosyl- $\beta$ - 1 -phosphomycoketide (MPM) is stimulatory in association with CD1c and its tail is composed of a single saturated alkane with methyl branches on every fourth carbon (Moody et al. 2000b; Matsunaga et al. 2004). CD1c-restricted T cells recognizing synthetic mycoketide expand in the blood of TB patients as compared with unin- fected controls (Moody et al. 2000b). Furthermore, an organism-wide survey has identified C32-phosphomycoketide (PM) from MTB as another CD1c-restricted lipid antigen (Ly et al. 2013).

Mycobacterial antigens that stimulate CD1drestricted $\mathrm{T}$ cells, which are not invariant natural killer (NK) T cells, have been identified (Tatituri et al. 2013). These lipid antigens comprised several phospholipids, such as phosphatidylglycerol, diphosphatidylglycerol (or cardiolipin), and phosphatidylinositol. The response to these antigens required antigen internalization and engagement of the TCR with the CD1d-lipid complex. Two important aspects of this type of antigen specificity remain to be clarified: (i) the role of these responses in patients with mycobacterial infections, because only mouse hybridoma cells were studied, and (ii) the potential reactivity with self-phospholipids that show identical structures to the bacterial ones.

\section{Functions of CD1-Restricted T Cells during Mycobacterial Infection}

The absence of group 1 CD1 genes in mice and rats and the limited availability of reliable tools to directly visualize ex vivo antigen-specific CD1-restricted $\mathrm{T}$ cells has severely hampered the progress in the study of lipid-specific T cells. However, in vivo and ex vivo data on the presentation of mycobacterial lipids in humans and other animal species have provided direct evidence of the function of CD1-specific T cells during mycobacterial infections. These studies showed that group $1 \mathrm{CD} 1$-restricted $\mathrm{T}$ cells have effector functions typical of T helper 1 (Th1), T helper 2 (Th2), and T helper 17 (Th17) cells, and that these functions increase during infection with MTB, suggesting their role in protection (Cohen et al. 2009). Experiments conducted with guinea pigs, which have an extended family of CD1 molecules, showed development of CD1b- and CD1c-restricted proliferative and cytolytic T-cell responses on immunization either by Mycobacterium bovis Bacillus CalmetteGuérin (BCG) or with partially purified lipid extracts of MTB (Hiromatsu et al. 2002; Watanabe et al. 2006). MTB-lipid-immunized guinea 
De Libero et al.

pigs had smaller lung lesions on challenge with MTB than vehicle-only-immunized animals (Dascher et al. 2003). In the cattle, which have $c d 1 a$ and $c d 1 b$ genes, a CD1b-restricted T-cell response could be detected after immunization with GMM (Nguyen et al. 2009). Studies conducted in TB patients suggested that CD1-restricted $\mathrm{T}$ cells are not infrequent and represent an important fraction of circulating $\mathrm{T}$ cells. We have shown the presence of cytolytic $\mathrm{Ac}_{2} \mathrm{SGL}$ specific CD1b-restricted T cells in latent TB individuals and active TB patients, but not in healthy donors (Gilleron et al. 2004). Ex vivo analysis of peripheral T cells has shown a CD1brestricted response against GroMM in latent TB and BCG-vaccinated individuals, but not in active TB patients or healthy donors (Layre et al. 2009). In contrast, GMM was recognized ex vivo by $\mathrm{T}$ cells from latent $\mathrm{TB}$ individuals only (Ulrichs et al. 2003). More recently, using GMM-loaded CD1b tetramers a small $\mathrm{CD}^{+}$ CD1b-restricted population was detected in TB patients (Kasmar et al. 2011). MA-specific CD1b-restricted $\mathrm{T}$ cells have been detected in the periphery and lungs of TB patients (Montamat-Sicotte et al. 2011). These T cells produced IFN- $\gamma$ and IL-2, showed effector and central memory phenotypes and were absent in BCGvaccinated individuals. Upon anti-TB therapy, MA-specific T cells contracted, became undetectable at 6 months post-initiation of treatment and exhibited recall expansion on antigen reencounter in vitro long after successful treatment, indicating persistence of lipid-specific memory $\mathrm{T}$ cells. The role of CD1-restricted responses in in vivo immune response was further strengthened by demonstration of the expansion of phosphomycoketide-specific CD1crestricted T cells (Moody et al. 2000b) and detection of DDM-specific CD1a-restricted T cells (Kasmar et al. 2013) in TB patients. The use of CD1 tetramers loaded with different lipid antigens has revealed that the number of circulating CD1-restricted T cells is in the same range of peptide-specific $\mathrm{T}$ cells, at least for tested CD1-antigen complexes. It remains to be investigated whether CD1-restricted $\mathrm{T}$ cells accumulate within tissues in which lipid-specific responses occur (i.e., skin, lung, gut, and liver), which might represent niches of preferential accumulation.

CD1d-restricted iNKT cells acquire an effector/memory phenotype and rapidly secrete large amounts of Th1 and Th2 cytokines on primary stimulation (Bendelac et al. 2007). iNKT cells contain preformed IFN- $\gamma$ mRNA in their cytoplasm, which promotes immediate secretion of this cytokine on TCR stimulation at levels 200 times higher than conventional MHC-restricted CD4 ${ }^{+} \mathrm{T}$ cells (Stetson et al. 2003). This secretion of cytokines is controlled by the strength of TCR signal received during antigen recognition (Wang et al. 2008), which depends on the number of CD1 complexes as well as their persistence on the surface of APCs. In addition, human NKT cells express granulysin (Gansert et al. 2003) that participates in killing intracellular bacteria resident within target cells. The effector capacities of iNKT cells contribute to the activation of other cells including DCs, NK cells, and $\mathrm{CD}^{+}{ }^{+}$and $\mathrm{CD}^{+} \mathrm{T}$ cells (Hermans et al. 2003), and thus iNKT cells can be considered as regulatory cells of adaptive immune responses. This function is important during mycobacterial infection for the expansion of $\mathrm{CD}^{+} \mathrm{T}$ cells that participate in protective immunity (Behar et al. 1999). Further, iNKT cells express a variety of chemokine receptors that may drive their traffic to inflamed tissues (Thomas et al. 2003). Intriguingly, iNKT cells display poor expression of the lymphoid homing receptors, CCR7 and CXCR5, suggesting that their function is mostly exerted in peripheral tissues rather than in peripheral lymphoid organs. Studies performed in mice infected with live mycobacteria or injected with purified MTB lipids provided evidence for the expansion, recruitment, and activation of iNKT cells (Ryll et al. 2001; Dieli et al. 2003) and suggested the importance of iNKT cells in the formation of granulomas (Gilleron et al. 2001). The importance of iNKT cells in antimycobacterial protective immunity has been further shown in experimental models using knockout animals with deletions in $c d 1 d$ or TCR J $\alpha 18$ genes (Chen et al. 1997; Sousa et al. 2000; Kawakami et al. 2002; Sugawara et al. 2002). The role of iNKT cells in controlling 
Nonclassical T Cells in Tuberculosis

MTB infection in humans is indirectly suggested by phenotypic observations showing variations as compared with healthy individuals (SnyderCappione et al. 2007; Im et al. 2008; Montoya et al. 2008). Thus, clear evidence of the role of iNKT cells in protection against TB is still formally lacking.

\section{Modulation of CD1 Expression and Evasion of CD1-Mediated Detection by MTB}

MTB has evolved a series of strategies to modulate the expression of CD1 molecules and to prevent CD1-restricted responses. MTB infection of human monocytes inhibits the expression of CD1 molecules and induces the generation of $\mathrm{CD} \mathrm{a}^{-}, \mathrm{CD} \mathrm{b}^{-}$, and $\mathrm{CD} 1 \mathrm{c}^{-} \mathrm{DCs}$ in the presence of IFN- $\alpha$ (Mariotti et al. 2002, 2004). This is attributed to cell wall-associated $\alpha$-glucans of MTB that through CR3 activate the p38 MAPK pathway, and in turn the ATF2 transcription factor (Gagliardi et al. 2007), leading to the inhibition of $c d 1$ gene transcription. MTB-infected monocytes differentiate into macrophage-like host cells and have reduced capacities to stimulate CD1-restricted T cells, thus representing an immunoprivileged niche for mycobacterial persistence. Other studies performed with CD1-expressing and mature DCs showed down-regulation of $c d 1$ gene transcription by MTB (Stenger et al. 1998), which was ascribed to engagement of Toll-like receptor 2 (TLR2) (Roura-Mir et al. 2005). Another important mechanism with potential effects on CD1-restricted lipid presentation is the inhibition of apoptosis of infected cells by MTB. As apoptosis is required for release of mycobacterial lipids and subsequent cross-presentation by CD1-expressing APCs (Schaible et al. 2003), its inhibition may also have indirect inhibitory effects on presentation of mycobacterial lipid antigens. The evolution of these evasion mechanisms suggests a protective role of CD1-restricted T-cell responses during MTB infection. Despite these in vitro compelling data, the physiological significance of CD1 protein down-regulation in vivo during mycobacterial infections remains to be investigated.

\section{MAIT CELLS}

MAIT cells are innate-like T lymphocytes present at high frequency in human blood (Martin et al. 2009). They were originally found enriched in the mucosal lamina propria, from where their name was derived (Treiner et al. 2003). Recently they also have been found to be a major population of liver-resident T cells (Dusseaux et al. 2011; Tang et al. 2013). MAIT cells express an evolutionarily conserved TCR- $\alpha$ chain characterized by the semi-invariant rearrangement $\mathrm{V} \alpha 7.2-\mathrm{J} \alpha 33$ in human and $\mathrm{V} \alpha 19-\mathrm{J} \alpha 33$ in mice paired with a limited set of $\mathrm{V} \beta$ chains, mainly $\mathrm{V} \beta 2$ and $\mathrm{V} \beta 13$ in humans and $\mathrm{V} \beta 6$ and V $\beta 8$ in mice (Porcelli et al. 1993; Tilloy et al. 1999; Treiner et al. 2003; Kawachi et al. 2006; Goldfinch et al. 2010).

\section{Antigens Stimulating MAIT Cells}

MAIT cells recognize pterin-containing compounds generated during the synthesis of riboflavin (vitamin $B_{2}$ ) by bacteria and yeasts (KjerNielsen et al. 2012) (Fig. 2A) and presented by nonpolymorphic MR1, which is the restriction element for these $\mathrm{T}$ lymphocytes (Treiner et al. 2003; Huang et al. 2005). MAIT cells react to APCs infected with a broad array of microbes able to synthesize riboflavin, whereas they are not stimulated by microbes that lack this capacity (Kjer-Nielsen et al. 2012). The responsiveness to a wide group of microorganisms suggests an important function of MAIT cells in antimicrobial immunity (Gold et al. 2010; Le Bourhis et al. 2010). Furthermore, MAIT cells are absent in the periphery of germ-free mice and their peripheral expansion depends on bacterial colonization (Treiner et al. 2005), thus further suggesting that they participate in the control of infections.

Structural studies have shown how the pterin-containing metabolites are inserted within the antigen-binding pocket of MR1 (Lopez-Sagaseta et al. 2013; Patel et al. 2013). The pocket is very large and delimited by hydrophilic and hydrophobic amino acids. Furthermore, the cocrystallized antigens showed a minimal occupancy of the groove, suggesting that additional 
De Libero et al.

A<smiles>Cc1nc2c(=O)[nH]c(=O)nc-2n(C[C@H](O)[C@H](O)CO)c1C</smiles>

RL-6,7-di-methyl<smiles>CC1=NC2C(NC(C)=C(O)N2C[C@@H](O)[C@H](O)CO)C(=O)N1</smiles>

RL-6-methyl-7-OH<smiles>O=c1[nH]c(=O)c(=O)[nH]c2c1N=C(CO)CN2C[C@H](O)[C@H](O)CO</smiles>

RL-6- $\mathrm{CH}_{2} \mathrm{OH}$

B

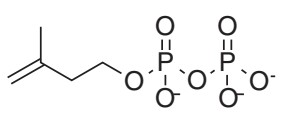

IPP

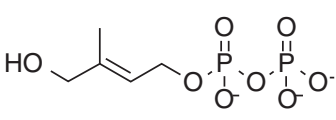

HMBPP

Figure 2. Structure of antigenic metabolites. (A) Structures of three different ribityl lumazines (RL), which bind MR1 and stimulate MAIT cells. (B) Structures of isopentenyl pyrophosphate (IPP) and (E)-4-hydroxy-3methyl-but-2-enyl pyrophosphate (HMBPP) metabolite antigens, which stimulate V $\gamma 9$-V $\delta 2 \mathrm{~T}$ cells.

large hydrophobic or hydrophilic molecules might also bind to MR1. There is no evidence so far that MR1 molecules can present other antigens to non-MAIT T cells.

\section{Role of MR1-Restricted T Cells in Mycobacterial Infections}

Mycobacteria, including MTB, Mycobacterium smegmatis, Mycobacterium abscessus, and BCG are potent stimulators of human and mouse MAIT cells (Gold et al. 2010; Le Bourhis et al. 2010; Chua et al. 2012). A recent work showed that MAIT cells are reduced in blood of pulmonary $\mathrm{TB}$ patients compared with individuals with latent TB and healthy controls (Gold et al. 2010). In this study the percentage of MTB-reactive T-cell clones restricted to MR1 was higher in healthy donors and LTB individuals compared with patients with active disease. These studies were performed by analyzing the ex vivo frequency of MAIT cells measuring TNF$\alpha$ release in response to MTB-infected epithelial cells. The reduction of MR1-restricted T cells in blood of patients with active TB was possibly attributed to migration of MAIT cells into the lung, the natural site of MTB infection. The same study showed that a small percentage of lung-infiltrating $\mathrm{T}$ cells expressing the TCR $V \alpha 7.2$ from two donors released TNF- $\alpha$ in response to MTB-infected APCs in an MR1-dependent manner. As MTB-infected primary lung epithelial cells stimulate MAIT cells, they might be involved in the activation of MAIT cells in the lung (Gold et al. 2010). Another study described a reduction of MAIT cells in blood of patients with pulmonary bacterial infections, including $\mathrm{TB}$, compared with healthy individuals (Le Bourhis et al. 2010). Here, MAIT cells were identified ex vivo by flow cytometry according to the coexpression of their specific markers TCR V 27.2 and CD161. The drawback of this alternative approach is the known downmodulation of CD161 marker following antigen recognition, which limits the number of cells identified as true MAIT. However, it is not biased by the intrinsic differential capacity of individual $\mathrm{T}$ cells to adapt and grow in vitro following cloning. Despite the intrinsic limitations of used techniques, both studies confirmed that the MAIT cell compartment is impaired in blood of TB patients (Gold et al. 2010; Le Bourhis et al. 2010). As MAIT cells disappear from circulating blood on infection, they might accumulate at the site of infection. If this is the case, these findings raise the question of whether 
MAIT cells accumulating in the lung are protective in the context of TB infection.

\section{Effector Functions of MAIT Cells}

Upon recognition of bacteria, including MTB, MAIT cells released large amounts of IFN- $\gamma$ and TNF- $\alpha$ (Dusseaux et al. 2011; Chua et al. 2012; Gold et al. 2013), which are crucial cytokines for an effective immune response against MTB (reviewed in O'Garra et al. 2013). Furthermore, they killed in vitro APCs infected with Escherichia coli and BCG (Chua et al. 2012; Gold et al. 2013), thus contributing to control of intracellular infection and to limiting of pathogen spreading. Indications of a putative protective function of MAIT cells are also being investigated using MR1-deficient mice (MR1 ${ }^{-/-}$), which lack MAIT cells. These mice mounted a less efficient immune response at early time points than wild-type (WT) mice following intraperitoneal infection with Klebsiella pneumoniae (Georgel et al. 2011). It is of note that, in the same study, no differences between WT and $\mathrm{MR}^{-/-}$mice were observed when the animals were infected with E. coli, Shigella dysenteriae, and Yersinia enterocolitica (Georgel et al. 2011), although these bacteria can stimulate MAIT cells (Kjer-Nielsen et al. 2012). A transient impaired ability to clear aerosol-administered BCG was also described in mice lacking MAIT cells, as highlighted by the higher bacterial counts in the lung of $\mathrm{MR}^{-/-}$animals compared with WTones (Chua et al. 2012). In keeping with this, MR1-deficient V $\alpha 19-\mathrm{J} \alpha 33$ transgenic mice, intravenously injected with M. abscessus, showed an increased bacterial burden in the spleen compared with their MR1sufficient counterpart (Le Bourhis et al. 2010). In another study, purified human MAIT cells were reprogrammed into induced pluripotent stem cells and redifferentiated back in vitro into MAIT cells (re-MAIT) (Wakao et al. 2013). Re-MAIT showed MAIT-like phenotype and properties in vitro and, when adoptively transferred into immune-compromised NOD/ SCID mice challenged with M. abscessus, elicited a protective function via a granulysin-dependent mechanism (Wakao et al. 2013). In all these studies the protective activity of MAIT cells was noticed only at the early stage of infection, in line with the innate-like properties of these T lymphocytes. Nevertheless, a more recent work showed that MAIT cells can also elicit longterm bacterial control in a mouse model of pulmonary infection with the live vaccine strain of Francisella tularensis (Meierovics et al. 2013). The investigators found that $\mathrm{CD}^{+}$and $\mathrm{CD} 8^{+}$ T-cell-depleted WT mice were resistant to a sublethal dose of $F$. tularensis, whereas MR1-deficient animals devoid of $\mathrm{CD} 4^{+}$and $\mathrm{CD} 8^{+} \mathrm{T}$ cells succumbed to the infection. These data represented, to our knowledge, the first report of an effective long-lasting antimicrobial role of MAIT cells in vivo. Importantly, the same study showed that MAIT cells accumulated in the lung of $F$. tularensis-challenged mice and induced a prompt recruitment of IFN- $\gamma$-producing $\mathrm{CD} 4^{+}$ and $\mathrm{CD}^{+} \mathrm{T}$ cells to the infected site. Indeed MR1-deficient animals showed no MAIT accumulation in the lung and a significant delay in the recruitment of adaptive conventional T cells, resulting in a lower efficiency in the clearing of the bacteria (Meierovics et al. 2013). Such characteristics resemble those of CD1d-restricted iNKT cells, which have been defined as a "bridge" between innate and adaptive immunity (reviewed in Brennan et al. 2013).

It is still unclear whether the accumulation of MAIT cells in inflamed tissues resulted from the migration of circulating MAIT cells or from the expansion of the tissue-resident MAIT cell pool. In some instances, human MAIT cells do not proliferate in vitro after antigen stimulation (Dusseaux et al. 2011; Cosgrove et al. 2013), which instead induces an apoptotic program in these T lymphocytes (Cosgrove et al. 2013). However, in other laboratories MAIT cells have been successfully expanded and cloned (Gold et al. 2010; Lepore et al. 2014), showing that they survive in vitro when provided with the right culture conditions. Furthermore, they express high levels of tissue homing markers and chemokine receptors and display a marked tropism for solid organs (Kawachi et al. 2006; Dusseaux et al. 2011; Gold et al. 2013; Tang et al. 2013; Wakao et al. 2013). According to these findings, tissue-resident MAIT cells might be crucial as 
De Libero et al.

the first line of defense against invading pathogens. The prompt reactivity of "tissue-patrolling" MAIT cells to microbes might be important in containing the initial phase of local infections, further sustained by the fast influx of MAIT cells from blood, driven by chemotactic signals. The inflammatory environment resulting from MAIT cell activation would be important for the rapid recruitment of the effectors of the adaptive immunity. Further studies will be needed to challenge this model and to better characterize the potential protective activity of MAIT cells in TB. The definition of their role in the orchestrated mucosal immune response in the lung, their ability to modulate and regulate the function of other immune cells, such as macrophages and neutrophils, important in the early immune response against MTB (O'Garra et al. 2013), and the molecular mechanisms governing their antibacterial capacity remain unsolved and debated issues.

\section{GAMMA-DELTA T CELLS}

$\mathrm{T}$ cells expressing the gamma-delta $(\gamma \delta)$ TCR represent the third population of nonclassical $\mathrm{T}$ cells in humans. The main characteristic of human $\gamma \delta \mathrm{T}$ cells is their expression of unique TCR heterodimers. Three main populations of $\gamma \delta$ T cells are detected: The most abundant population in circulating blood and secondary lymphoid organs expresses the V $\delta 2$ chain almost always paired with the V $\gamma 9$ chain. These TCR heterodimers are disulphide linked as they use the $\mathrm{C} \gamma 1$ constant region and are polyclonal. Junctional diversity is present in the CDR3 regions of both the TCR $\gamma$ and $\delta$ chains. The second main population expresses the $V \delta 1$ chain, which is paired with different $\mathrm{V} \gamma$ chains, mostly belonging to the $\mathrm{V} \gamma \mathrm{I}$ family ( $\mathrm{V} \gamma 2,3,4,5$, and 8). This population of $\gamma \delta \mathrm{T}$ cells is polyclonal and the TCR is not disulphide linked, as in most of the cases the $\mathrm{C} \gamma 2$ constant region is used. The V $\delta 1$-expressing cells are abundant in the lamina propria of the gut and in the intraepithelial spaces. Noteworthy, these cells are also found in the lung and in the skin. The third population of $\gamma \delta \mathrm{T}$ cells expresses the $\mathrm{V} \delta 3$ chain, which usually pairs with $\mathrm{V} \gamma$ chains of the V $\gamma \mathrm{I}$ family.

\section{Antigen Recognition by $\gamma \boldsymbol{\delta}$ Cells}

Although we know a lot about TCR gene use, tissue localization, and effector functions of $\gamma \delta$ $T$ cells, we remain quite unaware of the antigens that stimulate human $\gamma \delta \mathrm{T}$ cells. In addition, we have only partial information on the function of this T-cell population in TB.

The population expressing the TCR V $\gamma 9$ V反2 heterodimer recognizes phosphorylated metabolites, such as isopentenyl pyrophosphate (IPP) and (E)-4-hydroxy-3-methyl-but-2-enyl pyrophosphate (HMBPP), which are produced in the mevalonate and methyl erythritol pathways, respectively (Fig. 2B). IPP is made by eukaryotic and prokaryotic cells, whereas HMBPP is made only by some microorganisms, including MTB. IPP and HMBPP are very small molecules (245 and $262 \mathrm{Da}$, respectively) and require appropriate antigen presentation. Recently, it was reported that Butyrophilin $3 \mathrm{~A} 1$ (BTN3A1) is required for activation of $\mathrm{V} \gamma \mathrm{9}$ V82 cells (Harly et al. 2012) and that this molecule is involved in the presentation of both phosphorylated metabolites to the TCR V $\gamma 9$ V82 (Vavassori et al. 2013). Surface plasmon resonance and surface-enhanced Raman scattering showed a direct interaction of the TCR $\mathrm{V} \gamma 9$-V $\delta 2$ with BTN3A1, and the presence of IPP increased the binding (Vavassori et al. 2013). Studies performed with site-directed mutagenesis of TCR chains indicated that the TCR becomes activated only when several amino acids present in the CDR regions of both the TCR $\gamma$ and $\delta$ chains interact with the antigen-presenting molecule (Wang et al. 2010).

Interestingly, BCG-infected cells stimulated only a subset of $\mathrm{V} \gamma 9-\mathrm{V} \delta 2$ cells, and only a fraction of $\mathrm{V} \gamma 9-\mathrm{V} \delta 2$ cells expanded in vitro with synthetic HMBPP was reactive to infected cells (Spencer et al. 2008). Whether the differential response results from recognition of additional mycobacterial antigens or reflects differences in TCR avidity or variable expression of costimulatory/inhibitory molecules remains to be investigated. 
The antigens stimulating $\gamma \delta$ cells expressing non-V $\gamma 9$ chains and non-V82 chains remain poorly characterized. These cells can be activated during CMV infections, and one clone expressing a V $\delta 5-\mathrm{V} \gamma 4$ TCR was activated by the endothelial protein $\mathrm{C}$ receptor (Willcox et al. 2012). V $\delta 1$-expressing cells were also found to interact with the bacterial phycoerythrin protein in a manner resembling antigen-antibody recognition, without requirements for antigen processing or presentation by dedicated presenting molecules (Zeng et al. 2012).

A small number of non-V $\delta 2$ cells recognize glycolipids presented by CD1c and CD1d molecules (Faure et al. 1990; Spada et al. 2000; Bai et al. 2012). The structure of the TCR $\gamma \delta$-CD1lipid complex showed a MHC-like recognition (Luoma et al. 2013; Uldrich et al. 2013), disclosing the enormous plasticity of antigen recognition by TCR $\gamma \delta$. So far, there is no evidence of recognition of mycobacterial lipid antigens by $\gamma \delta$ cells. Recent studies reported the identification of two mycobacterial proteins, namely of 1-deoxy-D-xylulose 5-phosphate synthase 2 and Rv2272 protein, which activated $\gamma \delta$ T cells from pulmonary TB patients (Xi et al. 2013). Responding $\gamma \delta$ cells secreted IFN- $\gamma$ and monocyte chemoattractant protein 1 implicating an important role of these cells in protection and stimulation of monocyte chemotaxis toward the site of infection.

\section{Role of $\gamma \delta$ Cells in TB}

In TB patients many changes in $\gamma \delta$ cell populations have been detected for many years. However, molecular mechanisms and implications in protection and disease progression remain poorly characterized. Only in the recent past have novel mechanisms begun to be carefully investigated. In patients with active TB it was observed a decrease of circulating V $\gamma 9 \mathrm{~V} \delta 2$ cells and in particular of central memory cells and of effector memory and terminally differentiated cells, which exert immediate effector functions (Meraviglia et al. 2010). These changes reversed after antimycobacterial therapy, suggesting an indirect correlation with antigen burden. In severe TB patients, an increase of $\gamma \delta$ cells with enhanced interleukin-10 production was also described (Pinheiro et al. 2012), indicating changes associated with disease progression. This plasticity in T-cell function was confirmed in another study conducted in acute TB patients, in which a progressive reduction of the cytolytic activity of $\alpha \beta$ cells was described. However, in the same patients, $\gamma \delta$ cells remained perforin $^{+}$and capable of killing intracellular bacteria (De La Barrera et al. 2003).

The implication of $\gamma \delta$ cells in the immune response within MTB-infected lungs is supported by a series of investigations. V $\gamma 9 \mathrm{~V} \delta 2$ cells accumulate within lung granulomas (Huang et al. 2012), and in a macaque model of BCG and MTB infection they rapidly expanded upon second exposure to mycobacteria (Shen et al. 2002). This behavior resembles that of adaptive immunity cells and suggests that V $\gamma 9 \mathrm{~V} \delta 2$ cells may contribute to adaptive immunity to mycobacterial infections. In pleural effusions of TB patients, two populations of $\gamma \delta$ cells were identified as $\mathrm{TCR}^{\text {low }} \mathrm{V} \delta 2^{+}$and $\mathrm{TCR}^{\text {high }} \mathrm{V} \delta 1^{+}$ (Yokobori et al. 2009). The V $\delta 2$ cells were $\mathrm{CD}_{45 \mathrm{RA}^{+/}-} \mathrm{CCR7}^{+} \mathrm{CXCR}^{+}$, released large amounts of IFN- $\gamma$, and expressed the CD107a marker, indicating a status of activated cells within the tissue.

Finally, in a mouse model of lung infection with MTB, $\gamma \delta$ cells were instrumental to activate DCs in the lung and facilitate subsequent priming of lung CD8 cytotoxic T cells (Caccamo et al. 2006), thus representing important protagonists of the early response during infection.

\section{CONCLUDING REMARKS}

All together these studies depict nonclassical T cells as major players of the immune response during MTB infection. The capacity of these cells to recognize unique nonpeptidic antigens, together with their memory phenotype and effector capacities, represent good indications that they participate in protective mechanisms, alongside with MHC-restricted and peptidespecific T cells. Therefore, mycobacterial lipid antigens stimulating protective CD1-restricted T cells may be considered as candidate constituents of subunit anti-TB vaccines. 
De Libero et al.

A second important feature of other main populations of nonclassical T cells (MAIT and $\gamma \delta$ cells) is their recognition of small metabolites produced by most bacteria and their activation following TCR interaction with dedicated presenting molecules, such as MR1 and BTN3A1, which are both nonpolymorphic and almost ubiquitously expressed. These characteristics indicate a common strategy of tissue-resident nonclassical T-cell activation during early infection, which prompts immediate release of proinflammatory cytokines. This feature has not been exploited in animal models of TB and might represent a novel approach to facilitate early protection and efficient priming of adaptive T cells during MTB infection.

\section{ACKNOWLEDGMENTS}

We thank SIgN, University Hospital Basel, Swiss National Science Foundation, and European Union (NEWTBVAC) for support.

\section{REFERENCES}

Bai L, Picard D, Anderson B, Chaudhary V, Luoma A, Jabri B, Adams EJ, Savage PB, Bendelac A. 2012. The majority of CD1d-sulfatide-specific T cells in human blood use a semiinvariant V81 TCR. Eur J Immunol 42: 2505-2510.

Barral DC, Brenner MB. 2007. CD1 antigen presentation: How it works. Nat Rev Immunol 7: 929-941.

Barral DC, Cavallari M, McCormick PJ, Garg S, Magee AI, Bonifacino JS, De Libero G, Brenner MB. 2008. CD1a and MHC class I follow a similar endocytic recycling pathway. Traffic 9: 1446-1457.

Batuwangala T, Shepherd D, Gadola SD, Gibson KJ, Zaccai NR, Fersht AR, Besra GS, Cerundolo V, Jones EY. 2004 The crystal structure of human CD1b with a bound bacterial glycolipid. J Immunol 172: 2382-2388.

Beckman EM, Porcelli SA, Morita CT, Behar SM, Furlong ST, Brenner MB. 1994. Recognition of a lipid antigen by CD1-restricted $\alpha \beta+$ T cells. Nature 372: 691-694.

Behar SM, Dascher CC, Grusby MJ, Wang CR, Brenner MB. 1999. Susceptibility of mice deficient in CD1D or TAP1 to infection with Mycobacterium tuberculosis. J Exp Med 189: 1973-1980.

Bendelac A, Savage PB, Teyton L. 2007. The biology of NKT cells. Annu Rev Immunol 25: 297-336.

Brennan PJ, Brigl M, Brenner MB. 2013. Invariant natural killer T cells: An innate activation scheme linked to diverse effector functions. Nat Rev Immunol 13: 101-117.

Brossay L, Jullien D, Cardell S, Sydora BC, Burdin N, Modlin RL, Kronenberg M. 1997. Mouse CD1 is mainly expressed on hemopoietic-derived cells. J Immunol 159: 1216-1224.
Caccamo N, Sireci G, Meraviglia S, Dieli F, Ivanyi J, Salerno A. 2006. $\gamma \delta \mathrm{T}$ cells condition dendritic cells in vivo for priming pulmonary CD8 T cell responses against $M y c o-$ bacterium tuberculosis. Eur J Immunol 36: 2681-2690.

Chen YH, Chiu NM, Mandal M, Wang N, Wang CR. 1997. Impaired $\mathrm{NK}^{+}{ }^{+} \mathrm{T}$ cell development and early IL-4 production in CD1-deficient mice. Immunity 6: 459-467.

Chua WJ, Truscott SM, Eickhoff CS, Blazevic A, Hoft DF, Hansen TH. 2012. Polyclonal mucosa-associated invariant $\mathrm{T}$ cells have unique innate functions in bacterial infection. Infect Immun 80: 3256-3267.

Cohen NR, Garg S, Brenner MB. 2009. Antigen presentation by CD1 lipids, T cells, and NKT cells in microbial immunity. Adv Immunol 102: 1-94.

Cooper AM. 2009. Cell-mediated immune responses in tuberculosis. Annu Rev Immunol 27: 393-422.

Cosgrove C, Ussher JE, Rauch A, Gartner K, Kurioka A, Huhn MH, Adelmann K, Kang YH, Fergusson JR, Simmonds P, et al. 2013. Early and nonreversible decrease of CD161 $1^{++} /$MAIT cells in HIV infection. Blood 121: 951-961.

Dascher CC, Hiromatsu K, Xiong X, Morehouse C, Watts G, Liu G, McMurray DN, LeClair KP, Porcelli SA, Brenner MB. 2003. Immunization with a mycobacterial lipid vaccine improves pulmonary pathology in the guinea pig model of tuberculosis. Int Immunol 15: 915-925.

De La Barrera SS, Finiasz M, Frias A, Aleman M, Barrionuevo P, Fink S, Franco MC, Abbate E, del C Saslain M. 2003. Specific lytic activity against mycobacterial antigens is inversely correlated with the severity of tuberculosis. Clin Exp Immunol 132: 450-461.

de La Salle H, Mariotti S, Angenieux C, Gilleron M, GarciaAlles LF, Malm D, Berg T, Paoletti S, Maître B, Mourey L, et al. 2005. Assistance of microbial glycolipid antigen processing by CD1e. Science 310: 1321-1324.

De Libero G, Mori L. 2006. Mechanisms of lipid-antigen generation and presentation to T cells. Trends Immunol 27: 485-492.

De Libero G, Mori L. 2012. Novel insights into lipid antigen presentation. Trends Immunol 33: 103-111.

De Libero G, Collmann A, Mori L. 2009. The cellular and biochemical rules of lipid antigen presentation. Eur J Immunol 39: 2648-2656.

De Voss JJ, Rutter K, Schroeder BG, Su H, Zhu Y, Barry CE III. 2000. The salicylate-derived mycobactin siderophores of Mycobacterium tuberculosis are essential for growth in macrophages. Proc Natl Acad Sci 97: 1252-1257.

Dieli F, Taniguchi M, Kronenberg M, Sidobre S, Ivanyi J, Fattorini L, Iona E, Orefici G, De Leo G, Russo D, et al. 2003. An anti-inflammatory role for $\mathrm{V} \alpha 14 \mathrm{NK} \mathrm{T}$ cells in Mycobacterium bovis bacillus Calmette-Guérin-infected mice. J Immunol 171: 1961-1968.

Dougan SK, Kaser A, Blumberg RS. 2007. CD1 expression on antigen-presenting cells. Curr Top Microbiol Immunol 314: $113-141$.

Dusseaux M, Martin E, Serriari N, Peguillet I, Premel V, Louis D, Milder M, Le Bourhis L, Soudais C, Treiner E, et al. 2011. Human MAIT cells are xenobiotic-resistant, tissue-targeted, CD161hi IL-17-secreting T cells. Blood 117: $1250-1259$. 
Ernst WA, Maher J, Cho S, Niazi KR, Chatterjee D, Moody DB, Besra GS, Watanabe Y, Jensen PE, Porcelli SA, et al. 1998. Molecular interaction of CD1b with lipoglycan antigens. Immunity 8: 331-340.

Facciotti F, Cavallari M, Angenieux C, Garcia-Alles LF, Signorino-Gelo F, Angman L, Gilleron M, Prandi J, Puzo G, Panza L, et al. 2011. Fine tuning by human CD1e of lipidspecific immune responses. Proc Natl Acad Sci 108: $14228-14233$

Faure F, Jitsukawa S, Miossec C, Hercend T. 1990. CD1c as a target recognition structure for human T lymphocytes: Analysis with peripheral blood $\gamma / \delta$ cells. Eur J Immunol 20: 703-706.

Fischer K, Scotet E, Niemeyer M, Koebernick H, Zerrahn J, Maillet S, Hurwitz R, Kursar M, Bonneville M, Kaufmann SH, et al. 2004. Mycobacterial phosphatidylinositol mannoside is a natural antigen for CD1d-restricted T cells. Proc Natl Acad Sci 101: 10685-10690.

Gagliardi MC, Lemassu A, Teloni R, Mariotti S, Sargentini V, Pardini M, Daffe M, Nisini R. 2007. Cell wall-associated $\alpha$-glucan is instrumental for Mycobacterium tuberculosis to block CD1 molecule expression and disable the function of dendritic cell derived from infected monocyte. Cell Microbiol 9: 2081-2092.

Gansert JL, Kiessler V, Engele M, Wittke F, Rollinghoff M, Krensky AM, Porcelli SA, Modlin RL, Stenger S. 2003. Human NKT cells express granulysin and exhibit antimycobacterial activity. J Immunol 170: 3154-3161.

Garcia-Alles LF, Giacometti G, Versluis C, Maveyraud L, de Paepe D, Guiard J, Tranier S, Gilleron M, Prandi J, Hanau D, et al. 2011. Crystal structure of human CD1e reveals a groove suited for lipid-exchange processes. Proc Natl Acad Sci 108: 13230-13235.

Gau B, Lemetais A, Lepore M, Garcia-Alles LF, Bourdreux Y, Mori L, Gilleron M, De Libero G, Puzo G, Beau JM, et al. 2013. Simplified deoxypropionate acyl chains for $\mathrm{Myco}$ bacterium tuberculosis sulfoglycolipid analogues: Chain length is essential for high antigenicity. Chembiochem 14: 2413-2417.

Geerdink D, ter Horst B, Lepore M, Mori L, Puzo G, Hirsch AKH, Gilleron M, de Libero G, Minnaard AJ. 2013. Total synthesis, stereochemical elucidation and biological evaluation of $\mathrm{Ac}_{2} \mathrm{SGL}$; a 1,3-methyl branched sulfoglycolipid from Mycobacterium tuberculosis. Chem Sci 4: 709-716.

Georgel P, Radosavljevic M, Macquin C, Bahram S. 2011. The non-conventional MHC class I MR1 molecule controls infection by Klebsiella pneumoniae in mice. Mol Immunol 48: 769-775.

Gilleron M, Ronet C, Mempel M, Monsarrat B, Gachelin G, Puzo G. 2001. Acylation state of the phosphatidylinositol mannosides from Mycobacterium bovis bacillus Calmette-Guérin and ability to induce granuloma and recruit natural killer T cells. J Biol Chem 276: 34896-34904.

Gilleron M, Stenger S, Mazorra Z, Wittke F, Mariotti S, Bohmer G, Prandi J, Mori L, Puzo G, De Libero G. 2004. Diacylated sulfoglycolipids are novel mycobacterial antigens stimulating CD1-restricted T cells during infection with Mycobacterium tuberculosis. J Exp Med 199: 649-659.

Gold MC, Cerri S, Smyk-Pearson S, Cansler ME, Vogt TM, Delepine J, Winata E, Swarbrick GM, Chua WJ, Yu YY, et al. 2010. Human mucosal associated invariant $\mathrm{T}$ cells detect bacterially infected cells. PLoS Biol 8: e1000407.

Gold MC, Eid T, Smyk-Pearson S, Eberling Y, Swarbrick GM, Langley SM, Streeter PR, Lewinsohn DA, Lewinsohn DM. 2013. Human thymic MR1-restricted MAIT cells are innate pathogen-reactive effectors that adapt following thymic egress. Mucosal Immunol 6: 35-44.

Goldfinch N, Reinink P, Connelley T, Koets A, Morrison I, Van Rhijn I. 2010. Conservation of mucosal associated invariant T (MAIT) cells and the MR1 restriction element in ruminants, and abundance of MAIT cells in spleen. Vet Res 41: 62 .

Guiard J, Collmann A, Garcia-Alles LF, Mourey L, Brando T, Mori L, Gilleron M, Prandi J, De Libero G, Puzo G. 2009. Fatty acyl structures of Mycobacterium tuberculosis sulfoglycolipid govern T cell response. J Immunol 182: 7030 7037.

Han M, Hannick LI, DiBrino M, Robinson MA. 1999. Polymorphism of human CD1 genes. Tissue Antigens 54: $122-127$.

Harly C, Guillaume Y, Nedellec S, Peigne CM, Monkkonen H, Monkkonen J, Li J, Kuball J, Adams EJ, Netzer S, et al. 2012. Key implication of CD277/butyrophilin-3 (BTN3A) in cellular stress sensing by a major human $\gamma \delta$ T-cell subset. Blood 120: 2269-2279.

Hermans IF, Silk JD, Gileadi U, Salio M, Mathew B, Ritter G, Schmidt R, Harris AL, Old L, Cerundolo V. 2003. NKT cells enhance $\mathrm{CD} 4^{+}$and $\mathrm{CD} 8^{+} \mathrm{T}$ cell responses to soluble antigen in vivo through direct interaction with dendritic cells. J Immunol 171: 5140-5147.

Hiromatsu K, Dascher CC, LeClair KP, Sugita M, Furlong ST, Brenner MB, Porcelli SA. 2002. Induction of CD1restricted immune responses in guinea pigs by immunization with mycobacterial lipid antigens. J Immunol 169: 330-339.

Huang S, Gilfillan S, Cella M, Miley MJ, Lantz O, Lybarger L, Fremont DH, Hansen TH. 2005. Evidence for MR1 antigen presentation to mucosal-associated invariant $\mathrm{T}$ cells. J Biol Chem 280: 21183-21193.

Huang D, Chen CY, Zhang M, Qiu L, Shen Y, Du G, Zhou K, Wang R, Chen ZW. 2012. Clonal immune responses of mycobacterium-specific $\gamma \delta \mathrm{T}$ cells in tuberculous and non-tuberculous tissues during $M$. tuberculosis infection. PloS ONE 7: e30631.

Im JS, Kang TJ, Lee SB, Kim CH, Lee SH, Venkataswamy MM, Serfass ER, Chen B, Illarionov PA, Besra GS, et al. 2008. Alteration of the relative levels of iNKT cell subsets is associated with chronic mycobacterial infections. Clin Immunol 127: 214-224.

Kasmar AG, van Rhijn I, Cheng TY, Turner M, Seshadri C, Schiefner A, Kalathur RC, Annand JW, de Jong A, Shires J, et al. 2011. CD1b tetramers bind $\alpha \beta$ T cell receptors to identify a mycobacterial glycolipid-reactive $\mathrm{T}$ cell repertoire in humans. J Exp Med 208: 1741-1747.

Kasmar AG, Van Rhijn I, Magalhaes KG, Young DC, Cheng TY, Turner MT, Schiefner A, Kalathur RC, Wilson IA, Bhati M, et al. 2013. Cutting edge: CD1a tetramers and dextramers identify human lipopeptide-specific T cells ex vivo. J Immunol 191: 4499-4503.

Kawachi I, Maldonado J, Strader C, Gilfillan S. 2006. MR1restricted $\mathrm{V} \alpha 19 \mathrm{i}$ mucosal-associated invariant $\mathrm{T}$ cells are innate $\mathrm{T}$ cells in the gut lamina propria that provide a 
De Libero et al.

rapid and diverse cytokine response. J Immunol 176: $1618-1627$.

Kawakami K, Kinjo Y, Uezu K, Yara S, Miyagi K, Koguchi Y, Nakayama T, Taniguchi M, Saito A. 2002. Minimal contribution of $\mathrm{V} \alpha 14$ natural killer $\mathrm{T}$ cells to Th1 response and host resistance against mycobacterial infection in mice. Microbiol Immunol 46: 207-210.

Kjer-Nielsen L, Patel O, Corbett AJ, Le Nours J, Meehan B, Liu L, Bhati M, Chen Z, Kostenko L, Reantragoon R, et al. 2012. MR1 presents microbial vitamin B metabolites to MAIT cells. Nature 491: 717-723.

Layre E, Collmann A, Bastian M, Mariotti S, Czaplicki J, Prandi J, Mori L, Stenger S, De Libero G, Puzo G, et al. 2009. Mycolic acids constitute a scaffold for mycobacterial lipid antigens stimulating CD1-restricted T cells. Chem Biol 16: 82-92.

Le Bourhis L, Martin E, Peguillet I, Guihot A, Froux N, Core M, Levy E, Dusseaux M, Meyssonnier V, Premel V, et al. 2010. Antimicrobial activity of mucosal-associated invariant T cells. Nat Immunol 11: 701-708.

Lepore M, Kalinicenko A, Colone A, Paleja B, Singhal A, Tschumi A, Lee B, Poidinger M, Zolezzi F, Quagliata L, et al. 2014. Parallel T-cell cloning and deep sequencingof human MAIT cells reveal stable oligoclonal TCR $\beta$ répertoire. Nat Comm (in press).

Lopez-Sagaseta J, Dulberger CL, Crooks JE, Parks CD, Luoma AM, McFedries A, Van Rhijn I, Saghatelian A, Adams EJ. 2013. The molecular basis for mucosal-associated invariant $\mathrm{T}$ cell recognition of MR1 proteins. Proc Natl Acad Sci 110: E1771-E1778.

Luoma AM, Castro CD, Mayassi T, Bembinster LA, Bai L, Picard D, Anderson B, Scharf L, Kung JE, Sibener LV, et al. 2013. Crystal structure of V $\delta 1 \mathrm{~T}$ cell receptor in complex with CD1d-sulfatide shows MHC-like recognition of a self-lipid by human $\gamma \delta \mathrm{T}$ cells. Immunity 39: 1032-1042.

Ly D, Kasmar AG, Cheng TY, de Jong A, Huang S, Roy S, Bhatt A, van Summeren RP, Altman JD, Jacobs WR Jr, et al. 2013. CD1c tetramers detect ex vivo $T$ cell responses to processed phosphomycoketide antigens. J Exp Med 210: 729-741.

Madigan CA, Cheng TY, Layre E, Young DC, McConnell MJ, Debono CA, Murry JP, Wei JR, Barry CE III, Rodriguez GM, et al. 2012. Lipidomic discovery of deoxysiderophores reveals a revised mycobactin biosynthesis pathway in Mycobacterium tuberculosis. Proc Natl Acad Sci 109: 1257-1262.

Mariotti S, Teloni R, Iona E, Fattorini L, Giannoni F, Romagnoli G, Orefici G, Nisini R. 2002. Mycobacterium tuberculosis subverts the differentiation of human monocytes into dendritic cells. Eur J Immunol 32: 3050-3058.

Mariotti S, Teloni R, Iona E, Fattorini L, Romagnoli G, Gagliardi MC, Orefici G, Nisini R. 2004. Mycobacterium tuberculosis diverts $\alpha$ interferon-induced monocyte differentiation from dendritic cells into immunoprivileged macrophage-like host cells. Infect Immun 72: 4385-4392.

Martin E, Treiner E, Duban L, Guerri L, Laude H, Toly C, Premel V, Devys A, Moura IC, Tilloy F, et al. 2009. Stepwise development of MAIT cells in mouse and human. PLoS Biol 7: e54.

Matsunaga I, Bhatt A, Young DC, Cheng TY, Eyles SJ, Besra GS, Briken V, Porcelli SA, Costello CE, Jacobs WR Jr, et al. 2004. Mycobacterium tuberculosis pks12 produces a novel polyketide presented by CD1c to T cells. J Exp Med 200: 1559-1569.

Meierovics A, Yankelevich WJ, Cowley SC. 2013. MAIT cells are critical for optimal mucosal immune responses during in vivo pulmonary bacterial infection. Proc Natl Acad Sci 110: E3119-E3128.

Meraviglia S, Caccamo N, Salerno A, Sireci G, Dieli F. 2010. Partial and ineffective activation of $\mathrm{V} \gamma 9 \mathrm{~V} \delta 2 \mathrm{~T}$ cells by Mycobacterium tuberculosis-infected dendritic cells. J Immunol 185: 1770-1776.

Montamat-Sicotte DJ, Millington KA, Willcox CR, HingleyWilson S, Hackforth S, Innes J, Kon OM, Lammas DA, Minnikin DE, Besra GS, et al. 2011. A mycolic acid-specific $\mathrm{CD1}$-restricted $\mathrm{T}$ cell population contributes to acute and memory immune responses in human tuberculosis infection. J Clin Invest 121: 2493-2503.

Montoya CJ, Catano JC, Ramirez Z, Rugeles MT, Wilson SB, Landay AL. 2008. Invariant NKT cells from HIV-1 or Mycobacterium tuberculosis-infected patients express an activated phenotype. Clin Immunol 127: 1-6.

Moody DB, Guy MR, Grant E, Cheng TY, Brenner MB, Besra GS, Porcelli SA. 2000a. CD1b-mediated T cell recognition of a glycolipid antigen generated from mycobacterial lipid and host carbohydrate during infection. J Exp Med 192: 965-976.

Moody DB, Ulrichs T, Muhlecker W, Young DC, Gurcha SS, Grant E, Rosat JP, Brenner MB, Costello CE, Besra GS, et al. 2000b. CD1c-mediated T-cell recognition of isoprenoid glycolipids in Mycobacterium tuberculosis infection. Nature 404: 884-888.

Moody DB, Young DC, Cheng TY, Rosat JP, Roura-Mir C, O'Connor PB, Zajonc DM, Walz A, Miller MJ, Levery SB, et al. 2004. T cell activation by lipopeptide antigens. Science 303: 527-531.

Moody DB, Zajonc DM, Wilson IA. 2005. Anatomy of CD1lipid antigen complexes. Nat Rev Immunol 5: 387-399.

Nguyen TK, Koets AP, Santema WJ, van Eden W, Rutten VP, Van Rhijn I. 2009. The mycobacterial glycolipid glucose monomycolate induces a memory $\mathrm{T}$ cell response comparable to a model protein antigen and no $\mathrm{B}$ cell response upon experimental vaccination of cattle. Vaccine 27: $4818-4825$.

O'Garra A, Redford PS, McNab FW, Bloom CI, Wilkinson RJ, Berry MP. 2013. The immune response in tuberculosis. Annu Rev Immunol 31: 475-527.

Patel O, Kjer-Nielsen L, Le Nours J, Eckle SB, Birkinshaw R, Beddoe T, Corbett AJ, Liu L, Miles JJ, Meehan B, et al. 2013. Recognition of vitamin B metabolites by mucosalassociated invariant T cells. Nat Commun 4: 2142.

Pinheiro MB, Antonelli LR, Sathler-Avelar R, Vitelli-Avelar DM, Spindola-de-Miranda S, Guimaraes TM, TeixeiraCarvalho A, Martins-Filho OA, Toledo VP. 2012. CD4CD8- $\alpha \beta$ and $\gamma \delta$ T cells display inflammatory and regulatory potentials during human tuberculosis. PloS ONE 7: e50923.

Porcelli SA. 1995. The CD1 family: A third lineage of antigen-presenting molecules. Adv Immunol 59: 1-98.

Porcelli SA, Modlin RL. 1999. The CD1 system: Antigenpresenting molecules for $\mathrm{T}$ cell recognition of lipids and glycolipids. Annu Rev Immunol 17: 297-329. 
Porcelli S, Yockey CE, Brenner MB, Balk SP. 1993. Analysis of $\mathrm{T}$ cell antigen receptor (TCR) expression by human peripheral blood CD4-8- $\alpha / \beta$ T cells demonstrates preferential use of several V $\beta$ genes and an invariant TCR $\alpha$ chain. J Exp Med 178: 1-16.

Roark JH, Park SH, Jayawardena J, Kavita U, Shannon M, Bendelac A. 1998. CD1.1 expression by mouse antigenpresenting cells and marginal zone B cells. J Immunol 160: 3121-3127.

Rossjohn J, Pellicci DG, Patel O, Gapin L, Godfrey DI. 2012. Recognition of CD1d-restricted antigens by natural killer T cells. Nat Rev Immunol 12: 845-857.

Roura-Mir C, Wang L, Cheng TY, Matsunaga I, Dascher CC, Peng SL, Fenton MJ, Kirschning C, Moody DB. 2005. Mycobacterium tuberculosis regulates CD1 antigen presentation pathways through TLR-2. J Immunol 175: $1758-1766$.

Ryll R, Watanabe K, Fujiwara N, Takimoto H, Hasunuma R, Kumazawa Y, Okada M, Yano I. 2001. Mycobacterial cord factor, but not sulfolipid, causes depletion of NKT cells and upregulation of CD1d1 on murine macrophages. Microbes Infect 3: 611-619.

Schaible UE, Winau F, Sieling PA, Fischer K, Collins HL, Hagens K, Modlin RL, Brinkmann V, Kaufmann SH. 2003. Apoptosis facilitates antigen presentation to T lymphocytes through MHC-I and CD1 in tuberculosis. Nat Med 9: 1039-1046.

Seshadri C, Shenoy M, Wells RD, Hensley-McBain T, Andersen-Nissen E, McElrath MJ, Cheng TY, Moody DB, Hawn TR. 2013. Human CD1a deficiency is common and genetically regulated. J Immunol 191: 1586-1593.

Shen Y, Zhou D, Qiu L, Lai X, Simon M, Shen L, Kou Z, Wang Q, Jiang L, Estep J, et al. 2002. Adaptive immune response of $\mathrm{V} \gamma 2 \mathrm{~V} \delta 2^{+} \mathrm{T}$ cells during mycobacterial infections. Science 295: 2255-2258.

Siegrist MS, Unnikrishnan M, McConnell MJ, Borowsky M, Cheng TY, Siddiqi N, Fortune SM, Moody DB, Rubin EJ. 2009. Mycobacterial Esx-3 is required for mycobactinmediated iron acquisition. Proc Natl Acad Sci 106: 18792-18797.

Sieling PA, Chatterjee D, Porcelli SA, Prigozy TI, Mazzaccaro RJ, Soriano T, Bloom BR, Brenner MB, Kronenberg M, Brennan PJ, et al. 1995. CD1-restricted T cell recognition of microbial lipoglycan antigens. Science 269: 227-230.

Sloma I, Zilber MT, Vasselon T, Setterblad N, Cavallari M, Mori L, De Libero G, Charron D, Mooney N, Gelin C. 2008. Regulation of CD1a surface expression and antigen presentation by invariant chain and lipid rafts. J Immunol 180: $980-987$.

Snyder-Cappione JE, Nixon DF, Loo CP, Chapman JM, Meiklejohn DA, Melo FF, Costa PR, Sandberg JK, Rodrigues DS, Kallas EG. 2007. Individuals with pulmonary tuberculosis have lower levels of circulating CD1d-restricted NKT cells. J Infect Dis 195: 1361-1364.

Sousa AO, Mazzaccaro RJ, Russell RG, Lee FK, Turner OC, Hong S, Van Kaer L, Bloom BR. 2000. Relative contributions of distinct MHC class I-dependent cell populations in protection to tuberculosis infection in mice. Proc Natl Acad Sci 97: 4204-4208.

Spada FM, Grant EP, Peters PJ, Sugita M, Melian A, Leslie DS, Lee HK, van Donselaar E, Hanson DA, Krensky AM, et al. 2000. Self-recognition of CD1 by $\gamma / \delta$ T cells: Implications for innate immunity. J Exp Med 191: 937-948.

Spencer CT, Abate G, Blazevic A, Hoft DF. 2008. Only a subset of phosphoantigen-responsive $\gamma 9 \delta 2 \mathrm{~T}$ cells mediate protective tuberculosis immunity. J Immunol 181: 4471-4484.

Stenger S, Niazi KR, Modlin RL. 1998. Down-regulation of $\mathrm{CD} 1$ on antigen-presenting cells by infection with $\mathrm{Myco-}$ bacterium tuberculosis. J Immunol 161: 3582-3588.

Stetson DB, Mohrs M, Reinhardt RL, Baron JL, Wang ZE, Gapin L, Kronenberg M, Locksley RM. 2003. Constitutive cytokine mRNAs mark natural killer (NK) and NK T cells poised for rapid effector function. J Exp Med 198: 1069-1076.

Sugawara I, Yamada H, Mizuno S, Li CY, Nakayama T, Taniguchi M. 2002. Mycobacterial infection in natural killer T cell knockout mice. Tuberculosis (Edinb) 82: 97-104.

Tang XZ, Jo J, Tan AT, Sandalova E, Chia A, Tan KC, Lee KH, Gehring AJ, De Libero G, Bertoletti A. 2013. IL-7 licenses activation of human liver intrasinusoidal mucosal-associated invariant T cells. J Immunol 190: 3142-3152.

Tatituri RVV, Watts GFM, Bhowruth V, Barton N, Rothchild A, Hsu FF, Almeida CF, Cox LR, Eggeling L, Cardell S, et al. 2013. Recognition of microbial and mammalian phospholipid antigens by NKT cells with diverse TCRs. Proc Natl Acad Sci 110: 1827-1832.

Thomas SY, Hou R, Boyson JE, Means TK, Hess C, Olson DP, Strominger JL, Brenner MB, Gumperz JE, Wilson SB, et al. 2003. CD1d-restricted NKT cells express a chemokine receptor profile indicative of Th1-type inflammatory homing cells. J Immunol 171: 2571-2580.

Tilloy F, Treiner E, Park SH, Garcia C, Lemonnier F, de la Salle H, Bendelac A, Bonneville M, Lantz O. 1999. An invariant $\mathrm{T}$ cell receptor $\alpha$ chain defines a novel TAPindependent major histocompatibility complex class Ib-restricted $\alpha / \beta$ T cell subpopulation in mammals. $J$ Exp Med 189: 1907-1921.

Tourne S, Maitre B, Collmann A, Layre E, Mariotti S, Signorino-Gelo F, Loch C, Salamero J, Gilleron M, Angenieux C, et al. 2008. Cutting edge: A naturally occurring mutation in CDle impairs lipid antigen presentation. J Immunol 180: 3642-3646.

Treiner E, Duban L, Bahram S, Radosavljevic M, Wanner V, Tilloy F, Affaticati P, Gilfillan S, Lantz O. 2003. Selection of evolutionarily conserved mucosal-associated invariant T cells by MR1. Nature 422: 164-169.

Treiner E, Duban L, Moura IC, Hansen T, Gilfillan S, Lantz O. 2005. Mucosal-associated invariant T (MAIT) cells: An evolutionarily conserved T cell subset. Microbes Infect 7: $552-559$.

Uldrich AP, Le Nours J, Pellicci DG, Gherardin NA, McPherson KG, Lim RT, Patel O, Beddoe T, Gras S, Rossjohn J, et al. 2013. CD1d-lipid antigen recognition by the $\gamma \delta$ TCR. Nat Immunol 14: 1137-1145.

Ulrichs T, Moody DB, Grant E, Kaufmann SH, Porcelli SA. 2003. T-cell responses to CD1-presented lipid antigens in humans with Mycobacterium tuberculosis infection. Infect Immun 71, 3076-3087.

Van Rhijn I, Kasmar A, de Jong A, Gras S, Bhati M, Doorenspleet ME, de Vries N, Godfrey DI, Altman JD, de Jager W, et al. 2013. A conserved human $\mathrm{T}$ cell population 
De Libero et al.

targets mycobacterial antigens presented by CD1b. Nat Immunol 14: 706-713.

Vavassori S, Kumar A, Wan GS, Ramanjaneyulu GS, Cavallari M, El Daker S, Beddoe T, Theodossis A, Williams NK, Gostick E, et al. 2013. Butyrophilin 3A1 binds phosphorylated antigens and stimulates human $\gamma \delta \mathrm{T}$ cells. Nat Immunol 14: 908-916.

Wakao H, Yoshikiyo K, Koshimizu U, Furukawa T, Enomoto K, Matsunaga T, Tanaka T, Yasutomi Y, Yamada T, Minakami H, et al. 2013. Expansion of functional human mucosal-associated invariant $\mathrm{T}$ cells via reprogramming to pluripotency and redifferentiation. Cell Stem Cell 12: 546-558.

Wang X, Chen X, Rodenkirch L, Simonson W, Wernimont S, Ndonye RM, Veerapen N, Gibson D, Howell AR, Besra GS, et al. 2008. Natural killer T-cell autoreactivity leads to a specialized activation state. Blood 112: 4128-4138.

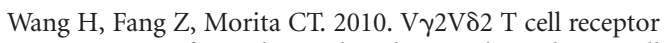
recognition of prenyl pyrophosphates is dependent on all CDRs. J Immunol 184: 6209-6222.

Watanabe Y, Watari E, Matsunaga I, Hiromatsu K, Dascher CC, Kawashima T, Norose Y, Shimizu K, Takahashi H, Yano I, et al. 2006. BCG vaccine elicits both T-cell mediated and humoral immune responses directed against mycobacterial lipid components. Vaccine 24: 5700-5707.

Willcox CR, Pitard V, Netzer S, Couzi L, Salim M, Silberzahn T, Moreau JF, Hayday AC, Willcox BE, Dechanet-Merville
J. 2012. Cytomegalovirus and tumor stress surveillance by binding of a human $\gamma \delta$ T cell antigen receptor to endothelial protein C receptor. Nat Immunol 13: 872-879.

Xi X, Han X, Li L, Zhao Z. 2013. Identification of a new tuberculosis antigen recognized by $\gamma \delta \mathrm{T}$ cell receptor. Clin Vaccine Immunol 20: 530-539.

Yokobori N, Schierloh P, Geffner L, Balboa L, Romero M, Musella R, Castagnino J, De Stefano G, Aleman M, de la Barrera S, et al. 2009. CD3 expression distinguishes two $\gamma \delta \mathrm{T}$ cell receptor subsets with different phenotype and effector function in tuberculous pleurisy. Clin Exp Immunol 157: 385-394.

Zajonc DM, Crispin MD, Bowden TA, Young DC, Cheng TY, $\mathrm{Hu}$ J, Costello CE, Rudd PM, Dwek RA, Miller MJ, et al. 2005. Molecular mechanism of lipopeptide presentation by CD1a. Immunity 22: 209-219.

Zeng X, Wei YL, Huang J, Newell EW, Yu H, Kidd BA, Kuhns MS, Waters RW, Davis MM, Weaver CT, et al. 2012. $\gamma \delta \mathrm{T}$ cells recognize a microbial encoded $\mathrm{B}$ cell antigen to initiate a rapid antigen-specific interleukin-17 response. Immunity 37: 524-534.

Zimmer MI, Nguyen HP, Wang B, Xu H, Colmone A, Felio K, Choi HJ, Zhou P, Alegre ML, Wang CR. 2009. Polymorphisms in CD1d affect antigen presentation and the activation of CD1d-restricted T cells. Proc Natl Acad Sci 106: 1909-1914. 


\section{$\&_{\mathrm{CSH}}^{\infty} \&$ Cold Spring Harbor

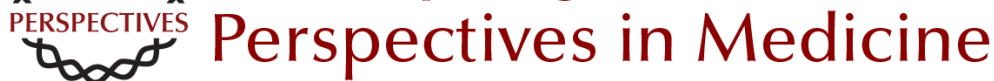

\section{Nonclassical T Cells and Their Antigens in Tuberculosis}

Gennaro De Libero, Amit Singhal, Marco Lepore and Lucia Mori

Cold Spring Harb Perspect Med 2014; doi: 10.1101/cshperspect.a018473 originally published online July 24,2014

\section{Subject Collection Tuberculosis}

Transmission and Institutional Infection Control of Tuberculosis Edward A. Nardell

Innate and Adaptive Cellular Immune Responses

to Mycobacterium tuberculosis Infection Katrin D. Mayer-Barber and Daniel L. Barber

Tuberculosis Comorbidity with Communicable and Noncommunicable Diseases

Matthew Bates, Ben J. Marais and Alimuddin Zumla

Host-Directed Therapies for Tuberculosis David M. Tobin

Immunity and Immunopathology in the

Tuberculous Granuloma

Antonio J. Pagán and Lalita Ramakrishnan

Tuberculosis Drug Development: History and

Evolution of the Mechanism-Based Paradigm? Sumit Chakraborty and Kyu Y. Rhee

Genetic Approaches to Facilitate Antibacterial

Drug Development

Dirk Schnappinger

The Tuberculosis Drug Discovery and

Development Pipeline and Emerging Drug Targets

Khisimuzi Mdluli, Takushi Kaneko and Anna Upton
Clinical Aspects of Adult Tuberculosis Robert Loddenkemper, Marc Lipman and Alimuddin Zumla

Advances in Diagnostic Assays for Tuberculosis Stephen D. Lawn

Diagnosis and Management of Latent

Tuberculosis Infection

Laura Muñoz, Helen R. Stagg and Ibrahim

Abubakar

Mycobacterial Growth

Iria Uhía, Kerstin J. Williams, Vahid Shahrezaei, et al.

Multidrug-Resistant Tuberculosis and Extensively

Drug-Resistant Tuberculosis

Kwonjune J. Seung, Salmaan Keshavjee and Michael L. Rich

The Mycobacterial Cell Wall--Peptidoglycan and

Arabinogalactan Luke J. Alderwick, James Harrison, Georgina S. Lloyd, et al.

Tuberculosis and HIV Coinfection Judith Bruchfeld, Margarida Correia-Neves and Gunilla Källenius

Imaging in Tuberculosis Jamshed B. Bomanji, Narainder Gupta, Parveen Gulati, et al.

For additional articles in this collection, see http://perspectivesinmedicine.cshlp.org/cgi/collection/ 